\title{
MODEL ANALISIS HARGA SATUAN KOMPONEN PEKERJAAN DI PROVINSI D.I.YOGYAKARTA BERDASARKAN PADA DATA HISTORIS PENAWARAN KONTRAKTOR
}

\author{
Vanita Kesumawati Yacub1, Henricus Priyosulistyo², Arief Setiawan Budi Nugroho ${ }^{3}$ \\ 1,2,3 Departemen Teknik Sipil, Fakultas Teknik, Universitas Gadjah Mada \\ Email: batinvani@gmail.com
}

\begin{abstract}
Construction projects always face up problems in estimating the unit price quickly inthe planning, implementation, and maintenance phases. Especially forbuilding maintenance works, the unit price (UP) estimation is often difficultnor inaccurate. A UP planning, usingthe highest local price issued by the local government, results in the higher UP compared to the market price. This research aims to develop an empirical model for UP estimation based on inflation rate and project locationas the parameters. The UP data were collected from contractors, having carried out building maintenace works in different locations, and price increase and locationindexes were used. The price increase index was obtained from inflation rate reffered to the government of Yogyakarta Province, and the work location indexwas based on Decree of Ministry of Public Works and Public Housing, entitled Unit Price Analysis for Public Works (No:28/PRT/M/2016). The UP data were analysed using the linear trend method. This study generates an empirical formula that can be used to estimate the UP in Yogyakarta. To use the model for Sleman, Kulonprogo and Gunung Kidul regencies, the location indexescan be used as multiplying factors. The result showed 36 models, only 4 modelsof them can be useto estimate the UP accurately with determination coefficient $\left(R^{2}\right)>0,7$.
\end{abstract}

Keywords: Cost estimate, Inflation, Location, Unit price

\begin{abstract}
ABSTRAK
Pekerjaan konstruksi selalu menghadapi permasalahan dalam memperkirakan harga satuan pekerjaan (HSP) dengan cepat dalam tahap perencanaan, pelaksanaan, sampai dengan perawatan. Secara khusus dalam pekerjaan perawatan, perkiraan HSPsering tidak mudah dan tidaktepat. Perencanaan HSP yang menggunakan HSP eceran tertinggi dari pemerintah daerah membuat perencanaan HSPlebih tinggi dari harga pasaran. Penelitian ini bertujuan untuk membuat modelprediksi HSP berdasarkan nilai inflasi dan lokasi pekerjaansebagai parameternya. Data HSP didapat dari para kontraktor yang telah melaksanakan pekerjaan perawatan bangunan gedungdari beberapa lokasi yang berbeda dan memperhitungkan indeks kenaikan harga dan indeks lokasi pekerjaan. Indeks kenaikan harga diperoleh dari laju inflasi yang didapat dari pemerintah Provinsi D.I.Yogyakarta sedangkan indeks lokasi pekerjaan didapat dari analisa harga satuan yang didasarkan pada Peraturan Menteri Pekerjaan Umum dan Perumahan Rakyat tentang Pedoman Analisis Harga Satuan Pekerjaan Bidang Pekerjaan Umum (No:28/PRT/M/2016). Data HSP di analisis dengan menggunakan metode trend linear. Kajian ini telah mendapatkan hasil model persamaan empirisestimasi HSP di kota Yogyakarta. Untuk lokasi kabupaten Sleman, Kulonprogo dan Gunung Kidul dilakukan dengan mengkalikan indeks lokasi pekerjaan untuk masing-masing kabupaten tersebut. Hasil analisis diketahui bahwa dari 36 model terdapat 4 model yang dapat digunakan untuk estimasi HSP secara cukup akurat dengan nilai koefisien determinasi $\left(R^{2}\right)>0,7$.
\end{abstract}

Kata kunci: Estimasi Biaya, Inflasi, Lokasi, Harga Satuan Pekerjaan 


\section{PENDAHULUAN}

Daerah Istimewa Yogyakarta (D.I.Y) merupakan daerah yang sedang berkembang dalam berbagai sektor, salah satunya sektor konstruksi. Perkembangan ini dapat dilihat dari banyaknya pembangunan gedung baru di provinsi D.I.Y yang sedang berjalan maupun yang telah selesai dibangun. Selain pembangunan gedung baru, pekerjaan perawatan bangunan gedung juga menjadi pekerjaan yang penting dan banyak dilakukan di provinsi D.I.Y. Pentingnya melakukan pekerjaan perawatan bangunan gedung agar bangunan gedung tetep laik fungsi. Salah satu tahapan awal yang dilakukan sebelum memulai pekerjaan yaitu melakukan perhitungan Rencana Anggaran Biaya (RAB). Analisis Harga Satuan Pekerjaan (AHSP) menjadi pedoman awal untuk melakukan perhitungan RAB.

Roring (2014) menjelaskan estimasi parametrik adalah proses estimasi biaya dengan menggunakan persamaan matematis hubungan biaya dengan satu atau beberapa parameter fisik yang berkaitan dengan item yang akan diestimasi. Pada teknik parametrik datahistoris digunakan untuk mengembangkan hubungan-hubungan biaya berdasarkan analisis statistik. Estimasi parametrik memprediksi siklus biaya suatu sistem, menggunakan model matematik yang terdiri dari sejumlah parameter dan berdasarkan data historis proyek. Musyafa (2016) menyebutkan estimasi biaya perlu dilakukan dengan cermatkarena dalam manajemen konstruksi, estimasiini memiliki peran fundamental.

Sariani (2011) menyebutkan estimasi biaya erat hubungannya dengan analisa biaya, yaitu pekerjaan yang menyangkut pengkajian biaya kegiatan-kegiatan terdahulu yang akan dipakai sebagai bahanuntuk menyusun perkiraan biaya. Nasril (2014) menyebutkan nilai estimasi tidak boleh melebihi dari harga satuan yang di tetapkan oleh pemerintah kabupaten/kota karena nilai harga ini merupakan nilai maksimum dalam estimasi biaya penggangaran untuk bangunan gedung pemerintah.

Muali (2015) menjelaskan tahap estimasi biaya dalam proyek merupakan elemen penting sehingga dibutuhkan model estimasi biaya. Sae Hyun Ji (2010) dalam penelitiannya mengatakan bahwa estimasi biaya proyek biasanya hanya menggunakan estimasi konvensional berdasarkan data yang sudah ada sebelumnya, sedangkan estimasi dengan menggunakan metode perpaduan antara estimasi konvensional dan metode statistik lebih baik, dalam hal stabilitas maupun akurasi. Roring (2014) juga menyebutkan estimasi memiliki peranyang sangat penting dalam penentuan cakupan suatu proyek. Masalah yang mendasar adalah tingkatakurasi dari suatu estimasi.

Jennyvera (2012) menyebutkan pentingnya keakuratan estimasi biaya proyek konstruksi gedung memiliki kompleksitas dan ketidakpastian yang tinggi, sehingga berbagai faktor dapat mempengaruhi proses dan biaya konstruksi tersebut. Oleh karena itu untuk meningkatkan kualitas dari hasil estimasi biaya konseptual ini diperlukan suatu permodelan estimasi berdasarkan database proyek-proyek sejenis sebelumnya. Fikri (2015) menyatakan estimasi biaya sangat signifikan pengaruhnya dan menjadisalah satu tolok ukur penting dalam mengevaluasi keberhasilan suatu proyek konstruksi. Selain itu, estimasi biaya juga menjadi unsur determinan dan menjadi pegangan dalam menformulasikan 
kebijakan yang akan ditempuh utamanya dalam menentukan besarnya biaya investasi atau anggaran yang harus dialokasikan setiap tahunnya.

Kissi (2017) menyebutkan bahwa pengaruh ekonomi memiliki kontribusi yang signifikan padaprediksi indeks harga tender. Salah satu faktor ekonomi yang berpengaruh pada komponen-komponen biaya konstruksi adalah inflasi.Pada tahap perbaikan atau perawatan bangunan juga diperlukan dalam sebuah perencanaan biaya yang tepat, dikarenakan pekerjaan perbaikan sangat bergantung pada tingkat kerusakan yang sangat bervariasi pada setiap bangunan. Faktor lain yang kemungkinan berpengaruh dalam perubahan biaya konstruksi adalah lokasi pekerjaan konstruksi.

Ibrahim (2008) menyebutkan bahwa harga satuan pekerjaan (HSP) adalah jumlahan harga bahan dan upah tenaga kerja berdasarkan perhitungan analisis. Harga bahan yang didapatkan di pasaran dan dikumpulkan dalam suatu daftar dinamakan daftar harga satuan bahan. Upah tenaga kerja yang didapatkan dilokasi, dikumpulkan dan dicatat dalam suatu daftar dinamakan daftar harga satuan upah. Harga satuan bahan dan upah tenaga kerjadi setiap daerah berbeda-beda, sehingga dalam menghitung dan menyusun anggaran biaya suatu bangunan/ proyek, harus berpedoman pada harga satuan bahan dan upah tenaga kerja di pasaran dan lokasi pekerjaan.

Touran (2015) mengatakan ketepatan estimasi biaya dipengaruhi oleh kompleksitas proyek, perlu dilakukan perhitungan komponen yang lebih akurat dengan memperhitungkan variasi koefisien dalam item pekerjaan. Pradnyadari (2017) menyebutkan dalam pelaksanaan konstruksi, dibutuhkan beberapa macam estimasi yang berbeda berdasarkan tujuan penggunaan dan peruntukannya

Permasalahan yang terjadi pada HSP perawatan bangunan gedung adalah perubahan harga upah dan bahan yang terjadi seiring dengan waktu mengakibatkan ketidaktepatan dalam memperkiraan HSP, untuk itu diperlukan cara dalam memperkirakan HSP yang akan digunakan. Data HSP yang digunakan didapat dari kontraktor yang telah melaksanakan pekerjaan perawatan bangunan gedung yang berasal dari tahun dan lokasi berbeda, oleh karena itu peneliti memperhitungkan indeks kenaikan harga dan indeks lokasi pekerjaan.

Kajian ini dilakukan di Provinsi D.I. Yogyakarta dengan mengambil beberapa data HSP kontrak pada pekerjaan perawatan bangunan gedung tahun 20132017, data yang digunakan adalah gedung perkantoran dengan kerusakan non struktural. Item pekerjaan yang digunakan dalam penelitian yaitu pekerjaan atap, pekerjaan langit-langit, pekerjaan dinding, pekerjaan plesteran, pekerjaan pengecatan, pekerjaan penutup lantai, pekerjaan pintu dan jendela, pekerjaan kunci dan kaca, dan pekerjaan sanitasi. Data laju inflasi yang digunakan dalam penelitian merupakan persentase laju inflasi di Provinsi D.I. Yogyakarta tahun 2014-2017.

Kajian ini bertujuan untuk mengetahui pengaruh waktu terhadap harga satuan komponen pekerjaan bangunan gedung dan membuat model estimasi harga satuan komponen pekerjaan. 


\section{METODE}

Kajian ini menggunakan data sekunder yang terdiri dari beberapa data HSP kontrak pada pekerjaan perawatan bangunan gedung di Provinsi D.I. Yogyakarta tahun 2013-2017. Data laju inflasi yang digunakan merupakan persentase laju inflasi di Provinsi D.I.Yogyakarta tahun 2014-2017 yang diperoleh dari Badan Pusat Statistik Provinsi D.I. Yogyakarta.

Data yang digunakan untuk membuat AHSP berdasarkan Peraturan Menteri Pekerjaan Umum No. 28/PRT/M/2016 tentang AHSP bidang pekerjaan umum, sedangkan untuk harga satuan material dan upah pekerja Kabupaten Sleman, Kulonprogo, Gunung Kidul dan Kota Yogyakarta menggunakan Peraturan Gubernur Daerah Istimewa Yogyakarta tahun 2013-2017 tentang standar harga barang dan jasa (SHBJ) daerah.

Data yang sudah didapatkan dari penyedia jasa dikelompokkan berdasarkan jenis pekerjaan dan spesifikasi. Pengelompokkan data dilakukan menggunakan program komputer Microsoft Excel.

a. Data laju inflasi yang di dapatkan dari BPS D.I. Yogyakarta kemudian dihitung indeks kenaikan harga.

b. Data AHSP di kabupaten Sleman, Kulonprogo dan Gunung Kidul, kemudian dihitung indeks lokasi pekerjaan masing-masing kabupaten.

c. Data HSP kemudian dikalikan dengan indeks kenaikan harga dan indeks lokasi pekerjaan.

d. Pemodelan HSP akan dilakukan dengan menggunakan Ms.Excel yang mana variabel $X$ berupa tahun dan variabel $Y$ berupa HSP Baru.

\section{HASIL DAN PEMBAHASAN}

Data yang digunakan dalam penelitian yaitu HSP yang didapat dari harga kontrak pada pekerjaan perawatan bangunan gedung sebanyak 36 data dari tahun 20132017 di Provinsi D.I.Yogyakarta yaitu di kota Yogyakarta, kabupaten Sleman, Kulonprogodan Gunung Kidul. Contoh data yang akan dianalisis disajikan di dalam Tabel 1.

Tabel 1. HSP Kontrak Pada Pekerjaan Dinding Bata Merah Tebal 1/2 Bata, Campuran 1 SP : 3 PP

\begin{tabular}{cccc}
\hline No & Tahun & $\begin{array}{c}\text { Lokasi } \\
\text { Pekerjaan }\end{array}$ & $\begin{array}{c}\text { HSP } \\
\text { (Kontrak) }\end{array}$ \\
\hline 1 & 2013 & Kulonprogo & Rp. 86.119,2500 \\
\hline 2 & 2013 & Sleman & Rp. 65.205,0000 \\
\hline 3 & 2014 & Kulonprogo & Rp. 90.123,5000 \\
\hline 4 & 2015 & Kulonprogo & Rp. 94.007,5000 \\
\hline 5 & 2015 & Gunung Kidul & Rp. 89.504,8750 \\
\hline 6 & 2016 & Sleman & Rp. 80.074,0000 \\
\hline 7 & 2016 & Sleman & Rp. 81.757,5000 \\
\hline 8 & 2016 & Sleman & Rp. 81.757,5000 \\
\hline 9 & 2017 & Yogyakarta & Rp. 99.719,0000 \\
\hline 10 & 2017 & Gunung Kidul & Rp. 102.920,000 \\
\hline
\end{tabular}

Pemodelan terdiri atas variabel $Y$ berupa HSP baru sedangkan variabel $X$ berupa tahun. HSP baru yang akan digunakan dalam penelitian berupa HSP kontrak yang telah dikalikan dengan indeks kenaikan harga dan indeks lokasi pekerjaan dikarenakan basis data HSP berasal dari tahun dan lokasi yang berbeda.

Perhitungan indeks kenaikan harga dilakukan dengan menggunakan data laju inflasi. Data laju inflasi yang digunakan merupakan persentase laju inflasi di Provinsi D.I. Yogyakarta tahun 2014-2017 yang diperoleh dari Badan Pusat Statistik Provinsi D.I. Yogyakarta, data-data tersebut ditampilkan di dalam Tabel 2. 
Model Analisis Harga ... (Vanita/ hal 118-132)

Tabel 2. Laju inflasi Provinsi D.I.Yogyakarta (BPSD.I.Yogyakarta)

\begin{tabular}{cc}
\hline Tahun & Inflasi (\%) \\
\hline 2014 & 6,59 \\
2015 & 3,09 \\
2016 & 2,29 \\
2017 & 4,20 \\
\hline
\end{tabular}

Analisis perhitungan indeks kenaikan harga dimulai dari tahun 2013-2017, dimana pada tahun 2013 sebesar 100\%.

Analisis perhitungan indeks kenaikana harga sebagai berikut.
a. Tahun $2013=100 \%=1,0000$
b. Tahun $2014=1,0000 \times\left(1+\frac{6,59}{100}\right)=$ 1,0659
c. Tahun $2015=1,0659 \times\left(1+\frac{3,09}{100}\right)=$ 1,0988
d. Tahun $2016=1,0988 \times\left(1+\frac{2,29}{100}\right)=$ 1,1240
e. Tahun $2017=1,1240 \times\left(1+\frac{4,20}{100}\right)=$ 1,1712

Rekapitulasi perhitungan indeks kenaikan harga dapat dilihat di dalam Tabel 3.

Tabel 3.Rekapitulasi Indeks Kenaikan Harga

\begin{tabular}{cc}
\hline Tahun & Variabel Inflasi \\
\hline 2013 & 1,0000 \\
2014 & 1,0659 \\
2015 & 1,0988 \\
2016 & 1,1240 \\
2017 & 1,1712 \\
\hline
\end{tabular}

Perhitungan indeks lokasi pekerjaan dilakukan dengan menghitung HSP menggunakan analisa Peraturan Menteri Pekerjaan Umum No. 28/PRT/M/2016 dan SHBJ menggunakan Peraturan Gubernur Daerah Istimewa Yogyakarta tahun 20132017 untuk Yogyakarta, Sleman, Kulonprogo, dan Gunung Kidul. 
Tabel 4. SHBJ kabupaten di D.I.Yogyakarta

\begin{tabular}{|c|c|c|c|c|c|c|c|c|c|}
\hline No. & Lokasi & Tahun & Tukang Batu & Kepala Tukang & Pekerja & Mandor & Bata Merah & Semen Portland & Pasir Pasang \\
\hline \multirow[t]{5}{*}{1} & Yogyakarta & 2013 & Rp.50.000 & Rp.60.000 & Rp.40.000 & Rp.45.000 & Rp. 1.000 & Rp. 1.500 & Rp.74.500 \\
\hline & & 2014 & Rp.55.000 & Rp.65.000 & Rp.47.500 & Rp.70.000 & Rp. 1.025 & Rp. 1.450 & Rp.97.900 \\
\hline & & 2015 & Rp.70.000 & Rp.70.000 & Rp. 60.000 & Rp.75.000 & Rp.1.000 & Rp. 1.000 & Rp. 165.000 \\
\hline & & 2016 & Rp.70.000 & Rp.70.000 & Rp.60.000 & Rp.75.000 & Rp. 1.000 & Rp. 1.000 & Rp.244.000 \\
\hline & & 2017 & Rp.70.000 & Rp.70.000 & Rp.60.000 & Rp.75.000 & Rp. 1.000 & Rp. 1.000 & Rp.244.000 \\
\hline \multirow{5}{*}{2} & Sleman & 2013 & Rp.50.000 & Rp.60.000 & Rp.40.000 & Rp.45.000 & Rp. 1.000 & Rp. 1.300 & Rp.148.500 \\
\hline & & 2014 & Rp.55.000 & Rp.65.000 & Rp.47.500 & Rp.70.000 & Rp. 1.025 & Rp. 1.450 & Rp.76.325 \\
\hline & & 2015 & Rp.70.000 & Rp.70.000 & Rp.60.000 & Rp.75.000 & Rp. 1.000 & Rp. 2.000 & Rp.165.000 \\
\hline & & 2016 & Rp.70.000 & Rp.70.000 & Rp.60.000 & Rp.75.000 & Rp. 1.000 & Rp. 2.000 & Rp.234.000 \\
\hline & & 2017 & Rp. 1.000 & Rp.70.000 & Rp.60.000 & Rp.75.000 & Rp. 1.000 & Rp. 2.000 & Rp.234.000 \\
\hline \multirow{5}{*}{3} & Kulonprogo & 2013 & Rp.50.000 & Rp.60.000 & Rp.40.000 & Rp.45.000 & Rp. 1.000 & Rp. 1.700 & Rp.82.500 \\
\hline & & 2014 & Rp.55.000 & Rp.65.000 & Rp.47.500 & Rp.70.000 & Rp. 1.025 & Rp. 1.750 & Rp.135.900 \\
\hline & & 2015 & Rp.70.000 & Rp.70.000 & Rp.60.000 & Rp.75.000 & Rp. 1.000 & Rp. 2.000 & Rp.170.000 \\
\hline & & 2016 & Rp.70.000 & Rp.70.000 & Rp.60.000 & Rp.75.000 & Rp. 1.000 & Rp. 2.000 & Rp.244.000 \\
\hline & & 2017 & Rp.70.000 & Rp.70.000 & Rp.60.000 & Rp.75.000 & Rp. 1.000 & Rp. 2.000 & Rp.244.000 \\
\hline \multirow[t]{5}{*}{4} & Gunung Kidul & 2013 & Rp.50.000 & Rp.60.000 & Rp.40.000 & Rp.45.000 & Rp. 1.000 & Rp. 1.600 & Rp.132.500 \\
\hline & & 2014 & Rp.55.000 & Rp.65.000 & Rp.47.500 & Rp.70.000 & Rp. 1.025 & Rp. 1.450 & Rp.152.200 \\
\hline & & 2015 & Rp.70.000 & Rp.70.000 & Rp.60.000 & Rp.75.000 & Rp. 1.000 & Rp. 1.000 & Rp.230.000 \\
\hline & & 2016 & Rp.70.000 & Rp.70.000 & Rp.60.000 & Rp.75.000 & Rp. 1.000 & Rp. 1.000 & Rp.263.000 \\
\hline & & 2017 & Rp.70.000 & Rp.70.000 & Rp.60.000 & Rp.234.000 & Rp. 1.000 & Rp. 1.000 & Rp.263.000 \\
\hline
\end{tabular}


Rekapitulasi perhitungan HSP berdasarkan SHBJ ditampilkan di dalam Tabel 5.Contoh perhitungan HSP berdasarkan SHBJ di kota Yogyakarta disajikan di dalam Tabel6. Selanjutnya dilakukan perhitungan untuk kabupaten Sleman, Kulonprogo dan Gunung Kidul dengan langkah-langkah perhitungan yang sama.

Tabel 5. HSP $1 \mathrm{~m}^{2}$ Dinding Bata Merah Tebal 1/2 Bata, Campuran 1 SP : 3 PP Tahun 2013 Kabupaten Yogyakarta

\begin{tabular}{|c|c|c|c|c|}
\hline Uraian & Sat. & Koef. & $\begin{array}{c}\text { Harga } \\
\text { Satuan } \\
(R p)\end{array}$ & $\begin{array}{c}\text { Jumlah } \\
\text { (Rp) }\end{array}$ \\
\hline \multicolumn{5}{|l|}{$\begin{array}{l}\text { Tenaga } \\
\text { Kerja }\end{array}$} \\
\hline \multicolumn{2}{|c|}{ Tukang BatuOH } & 0,100 & 50.000 & 5.000 \\
\hline $\begin{array}{l}\text { Kepala } \\
\text { Tukang }\end{array}$ & $\mathrm{OH}$ & 0,010 & 60.000 & 600 \\
\hline Pekerja & $\mathrm{OH}$ & 0,300 & 40.000 & 12.000 \\
\hline Mandor & $\mathrm{OH}$ & 0,015 & 45.000 & 675 \\
\hline \multicolumn{5}{|l|}{ Bahan } \\
\hline Bata Merah & $\mathrm{m}^{3}$ & 70,00 & 1.000 & 70.000 \\
\hline $\begin{array}{l}\text { Semen } \\
\text { Portland }\end{array}$ & $\mathrm{kg}$ & 14,37 & 1.500 & 21.555 \\
\hline $\begin{array}{l}\text { Pasir } \\
\text { Pasang }\end{array}$ & $\mathrm{m}^{3}$ & 0,04 & 74.500 & 2.980 \\
\hline \multicolumn{4}{|c|}{ Jumlah Bahan } & 94.535 \\
\hline \multicolumn{4}{|c|}{ Jumlah Tenaga Kerja dan Bahan } & 112.810 \\
\hline \multicolumn{4}{|c|}{ Harga Satuan Pekerjaan Per- $\mathrm{m}^{3}$} & 112.810 \\
\hline
\end{tabular}

Tabel 6. Rekapitulasi HSP $1 \mathrm{~m}^{2}$ Dinding Bata Merah Tebal 1/2 Bata, Campuran 1 SP : 3 PP

\begin{tabular}{lccccc}
\hline \multicolumn{1}{c}{ Wil. } & $\begin{array}{c}\mathbf{2 0 1 3} \\
\mathbf{( R p )}\end{array}$ & $\begin{array}{c}\mathbf{2 0 1 4} \\
\mathbf{( R p )}\end{array}$ & $\begin{array}{c}\mathbf{2 0 1 5} \\
\mathbf{( R p )}\end{array}$ & $\begin{array}{c}\mathbf{2 0 1 6} \\
\mathbf{( R p )}\end{array}$ & $\begin{array}{c}\mathbf{2 0 1 7} \\
\mathbf{( R p )}\end{array}$ \\
\hline Yogyakarta 112.810117 .953117 .795 & 120.955120 .955 \\
Sleman & 112.896117 .090132 .165134 .925134 .925 \\
Kulonprogo 116.004 & 123.784132 .365135 .325135 .325 \\
Gunung & 116.567120 .125120 .395121 .715121 .715 \\
Kidul & & \\
\hline
\end{tabular}

Contoh perhitungan indeks lokasi pekerjaan pada Kabupaten Sleman tahun 2013:

a. Yogyakarta $=112.810$

b. Sleman $=112.896$

Persentase selisih HSP sleman terhadap Yogyakarta $=\frac{112.896-112.810}{112.810} \times \quad 100 \%=$ $0,0762 \%$
Indeks lokasi pekerjaan Sleman terhadap Yogyakarta $=\frac{100 \%}{100 \%+0,0762 \%}=0,9992$

Indeks lokasi pekerjaan Yogyakarta (YK) terhadap Sleman $=\frac{100 \%+0,0762 \%}{100 \%}=1,0008$

Selanjutnya dilakukan perhitungan pada tahun 2013-2017 untuk kabupaten Sleman (SLM), Kulonprogo (KP) dan Gunung Kidul (GK) dengan langkah-langkah perhitungan yang sama. Rekapitulasi perhitungan indeks lokasi pekerjaan kabupaten Sleman, Kulonprogodan Gunung Kidulditampilkan di dalam Tabel 7.

Tabel 7 Rekapitulasi Indeks Lokasi Pekerjaan

\begin{tabular}{llllll}
\hline \multirow{2}{*}{ Tahun } & \multicolumn{2}{c}{ Sleman } & \multicolumn{2}{c}{ Kulonprogo Gunung Kidul } \\
\cline { 2 - 6 } & SLM-YK & YK-SLM KP-YK & YK-KP & GK-YK & YK-GK \\
\hline 2013 & 0,9992 & 1,0008 & $0,97251,0283$ & 0,9678 & 1,0333 \\
2014 & 1,0074 & 0,9927 & $0,95291,0494$ & 0,9819 & 1,0184 \\
2015 & 0,8913 & 1,1220 & $0,88991,1237$ & 0,9784 & 1,0221 \\
2016 & 0,8965 & 1,1155 & $0,89381,1188$ & 0,9938 & 1,0063 \\
2017 & 0,8965 & 1,1155 & $0,89381,1188$ & 0,9938 & 1,0063 \\
\hline Rata-Rata & 1,0693 & 1,0878 & 1,0173 \\
\hline
\end{tabular}

Rekapitulasi data input yang akan dianalisis pada pekerjaan $1 \mathrm{~m}^{2}$ dinding bata merah tebal $1 / 2$ bata, campuran $1 \mathrm{SP}: 3$ PP ditampilkan di dalam Tabel 8.

Tabel 8 Rekapitulasi Data Input untuk Pekerjaan $1 \mathrm{~m}^{2}$ Dinding Bata Merah Tebal 1/2 Bata, Campuran $1 \mathrm{SP}: 3 \mathrm{PP}$

\begin{tabular}{|c|c|c|c|}
\hline Thn Lokasi & HSP & $\begin{array}{cc}\text { Indeks } & \text { Indeks } \\
\text { Kenaikan Lokasi } & \text { Lokarga Pekerjaa } \\
\text { Harga }\end{array}$ & $\begin{array}{l}\text { s } \\
\text { si HSP Baru } \\
\text { aan }\end{array}$ \\
\hline (2) & (3) & (4) (5) & $(6)=(3) \times(4) \times$ \\
\hline $013 \mathrm{KP}$ & $\begin{array}{c}86.119,250 \\
0\end{array}$ & $1,0000 \quad 0,9725$ & 83,7 \\
\hline LM & $\begin{array}{c}65.205,000 \\
0\end{array}$ & 0,9992 & 65,15 \\
\hline $2014 \mathrm{KP}$ & $\begin{array}{c}90.123,500 \\
0\end{array}$ & $1,06590,9529$ & 91,53 \\
\hline $2015 \mathrm{KP}$ & $\begin{array}{c}94.007,500 \\
0\end{array}$ & $1,09880,8899$ & $91,928.2934$ \\
\hline $2015 \mathrm{GK}$ & $\begin{array}{c}89.504,875 \\
0\end{array}$ & $1,09880,9784$ & 96,22 \\
\hline 2016 SLM $^{\varepsilon}$ & $\begin{array}{c}80.074,000 \\
0\end{array}$ & 00,8965 & 80,68 \\
\hline 2016 SLM & $\begin{array}{c}81.757,500 \\
0\end{array}$ & 0 0,8965 & $82,380.6440$ \\
\hline 2016 SLM $^{\varepsilon}$ & $\begin{array}{c}81.757,500 \\
0\end{array}$ & 1,12400 & $82,380.6440$ \\
\hline
\end{tabular}




\begin{tabular}{lcccc}
\hline Thn Lokasi & HSP & $\begin{array}{c}\text { Indeks } \\
\text { Kenaikan } \\
\text { Harga }\end{array}$ & $\begin{array}{c}\text { Indeks } \\
\text { Pekerjaan }\end{array}$ \\
\hline 2017 YK & $\begin{array}{c}99.719,000 \\
0\end{array}$ & 1,1712 & 1,0000 & $116,791.6554$ \\
2017 GK & $102.920,0001,1712$ & 0,9938 & $119,788.0236$ \\
\hline
\end{tabular}

Dalam pemodelan HSP akan dilakukan dengan menggunakan data input pada Tabel 11. Analisa akan dilakukan dengan menggunakan Ms.Excel yang mana variabel $X$ berupa tahun dan variabel $Y$ berupa HSP Baru. Hasil analisis dapat dilihat pada Gambar 1.

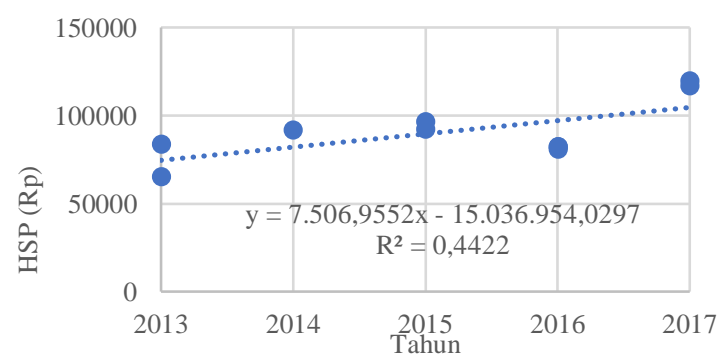

Gambar 1. HSP Pada Pekerjaan $1 \mathrm{~m}^{2}$ Dinding Bata Merah Tebal 1/2 Bata, Campuran 1 SP : 3 PP Terhadap Waktu

Gambar 1 menunjukkan bahwa HSP Pemasangan $1 \mathrm{~m}^{2}$ Dinding Bata Merah Tebal 1/2 Bata, Campuran 1 SP : 3 PP diperoleh persamaan

$Y=7506,9552 X-15036954,0297$

dengan nilai $\left(R^{2}\right)$ sebesar 0,4422 . Model estimasi HSP pada pekerjaan $1 \mathrm{~m}^{2}$ Dinding Bata Merah Tebal 1/2 Bata, Campuran 1 SP : 3 PP mempunyai nilai koefisien determinasi $\left(R^{2}\right)$ sebesar 0,4422 . Hal ini berarti bahwa 44,22\% variasi variabelHSP $(\mathrm{Y})$ dipengaruhi oleh variabel tahun (X) sedangkan sisanya (100\%$44,22 \%=55,78 \%$ ) dipengaruhi oleh sebab-sebab lain yang tidak diteliti.

Berdasarkan hasil analisis didapatkan model HSP pada pekerjaan $1 \mathrm{~m}^{2}$ dinding bata merah tebal 1/2 bata, campuran $1 \mathrm{SP}$ : 3 PP kota Yogyakarta sebagai berikut. $Y=7506,9552 x-15036954,0297$
Keterangan :

$Y$ : HSP $1 \mathrm{~m}^{2}$ dinding bata merah tebal $1 / 2$ bata, campuran $1 \mathrm{SP}: 3 \mathrm{PP}$

$X$ : tahun

Estimasi HSP pada pekerjaan $1 \mathrm{~m}^{2}$ dinding bata merah tebal $1 / 2$ bata, campuran $1 \mathrm{SP}$ : 3 PP pada tahun 2018 di kota Yogyakarta sebagai berikut.

$Y=7506,9552 X-15036954,0297$

$Y=7506,9552 \times 2018-15036954,0297$

$Y=R p .112 .082$

Perhitungan estimasi HSP pada pekerjaan $1 \mathrm{~m}^{2}$ dinding bata merah tebal $1 / 2$ bata, campuran $1 \mathrm{SP}$ : 3 PP di kabupaten Sleman, Kulonprogo dan Gunung Kidul pada tahun 2018 dilakukan dengan cara mengkalikan hasil perhitungan model $(Y)$ dengan indeks lokasi pekerjaan di setiap kabupaten.

HSP Kabupaten Sleman

$=$ Rp. $112.082 \times 1,0693$

$=$ Rp. 119.847

HSP Kabupaten Kulonprogo

$=$ Rp. $112.082 \times 1,0878$

$=$ Rp. 121.923

HSP Kabupaten GunungKidul

$=$ Rp. $112.082 \times 1,0173$

$=$ Rp. 114.017

Tingkat akurasi suatu modelling dalam estimasi harga dipengaruhi oleh jumlah data, keseragaman, dan pola sebaran basis data yang digunakan sebagai data analisa. Kenyataan di lapangan, data yang di peroleh sangat bervariasi dan mempunyai perbedaan dalam komponen data maupun isinya, hal itu di sebabkan karenadata yang diperolehpeneliti berasal dari kontraktor yang berbeda. Faktor-faktor tersebut menyebabkan kesulitan dalam mendapatkan keseragaman data dan pola sebaran data yang baik. 
Berdasarkan pada analisa data yang dilakukan dapat diketahui bahwa dalam penelitian ini ditemukan beberapa permasalahan sebagai berikut.

a. Jumlah data HSP yang didapatkan oleh peneliti sangat terbatas karena data HSP kontrak merupakan data penting yang bersifat rahasia.

b. Data HSP yang didapatkan mempunyai item pekerjaan yang berbeda-beda dikarenakan kebutuhan item pekerjaan dalam perawatan bangunan gedung bergantung pada kerusakan yang terjadi pada bangunan gedung. c. Tidak semua HSP yang terdapat pada data HSP kontrak pada pekerjaan perawatan gedung dapat digunakan dalam analisis disebabkan seluruh data di kelompokkan berdasarkan kategori dan item pekerjaan yang sama, sehingga item pekerjaan yang terdiri dari sedikit data tidak dapat digunakan dalam analisis.

Berdasarkan hasil analisis didapatkan kurva model harga satuan komponen pekerjaan dan diagram indeks lokasi pekerjaan (Gambar 2 dan Gambar 3). 


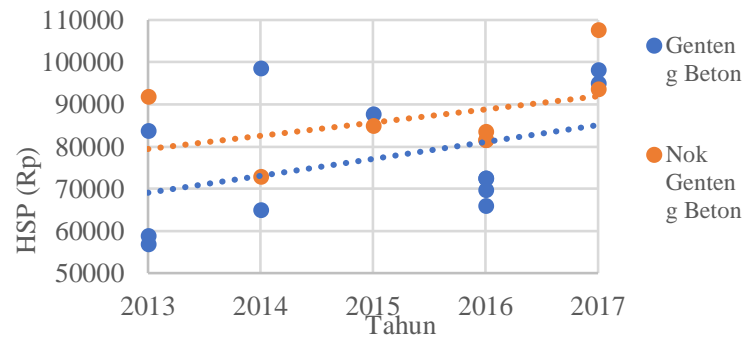

(a) Pekerjaan Atap

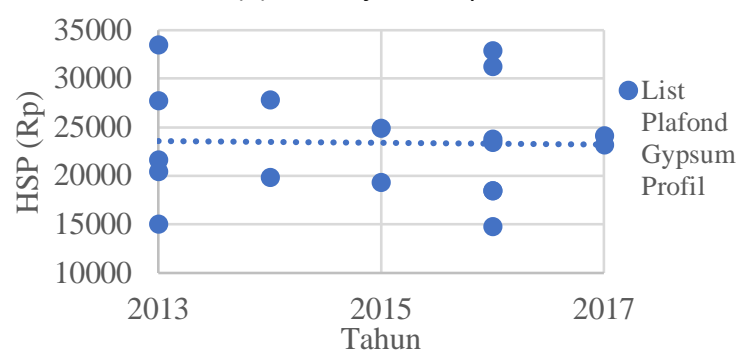

(b) Pekerjaan Langit-Langit

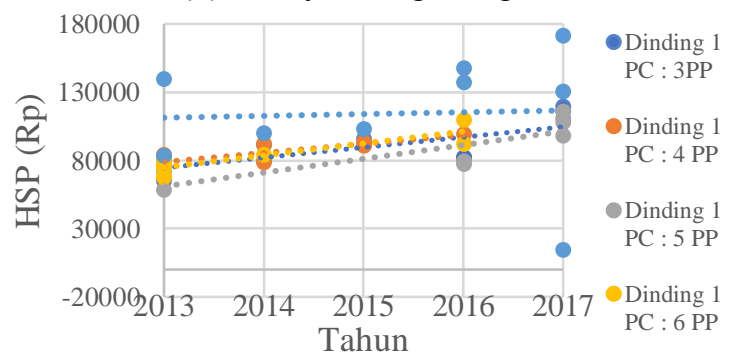

(c) Pekerjaan Dinding

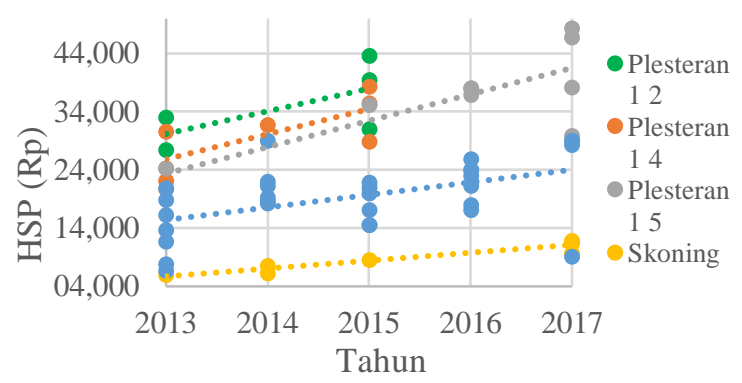

(d) Pekerjaan Plesteran

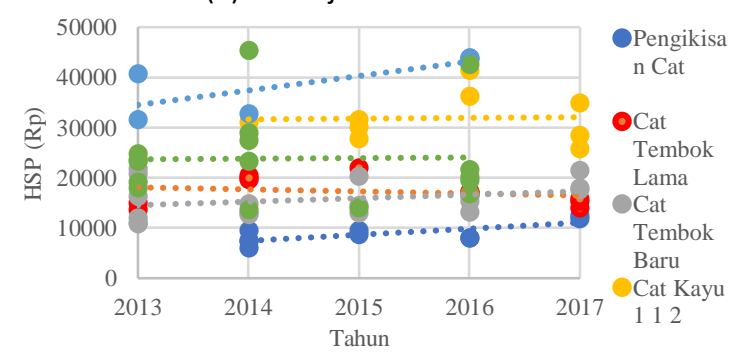

(e) Pekerjaan Cat

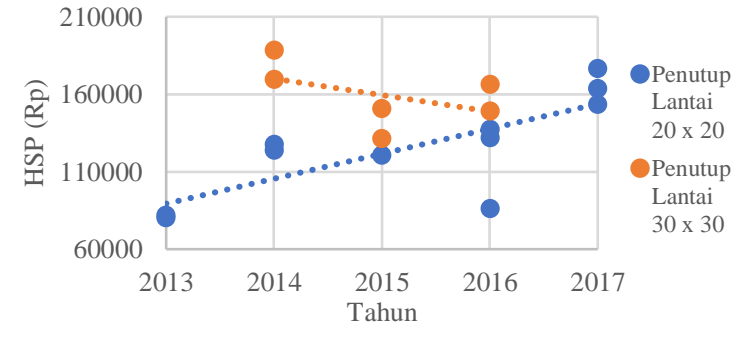

(f) Pekerjaan Penutup Lantai

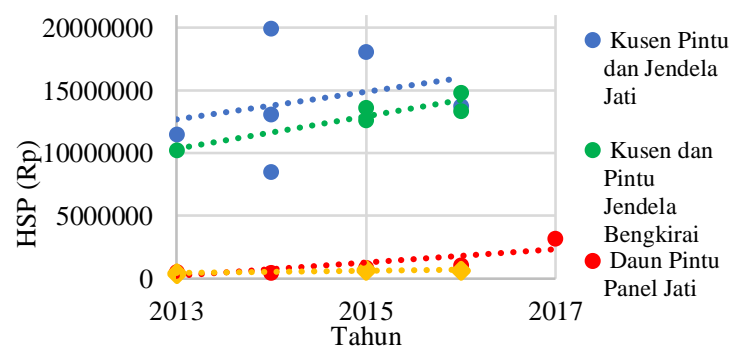

(g) Pekerjaan pintu dan Jendela

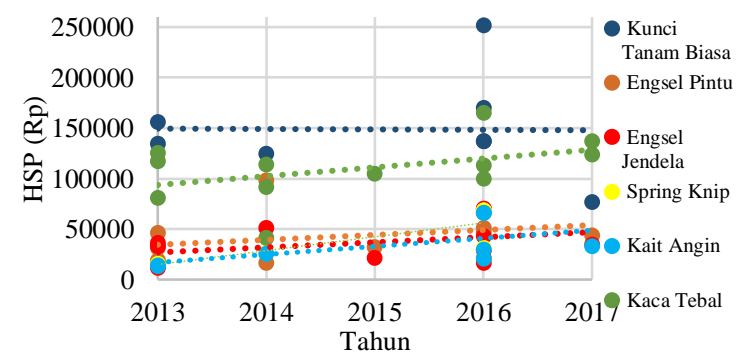

(h) Pekerjaan Kunci dan Kaca

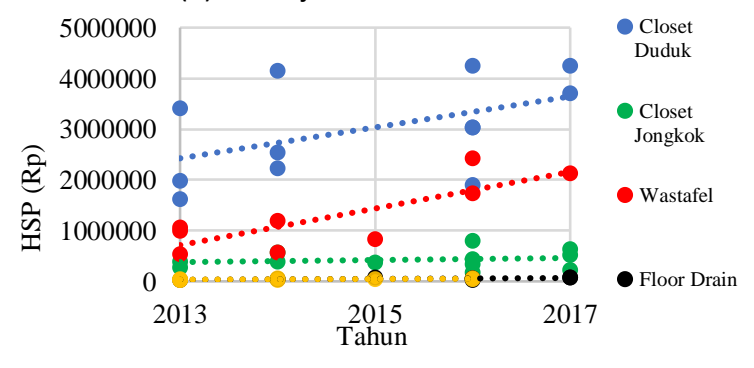

(i) Pekerjaan Sanitasi

Gambar 2. Hubungan HSP terhadap Waktu. 
Model Analisis Harga ... (Vanita/ hal 118-132)

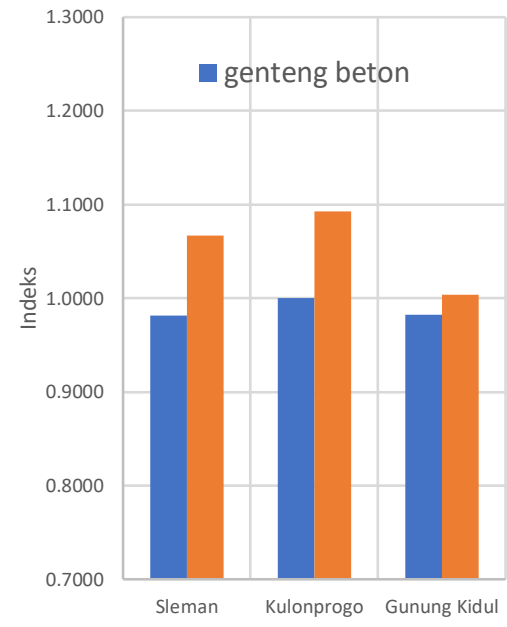

(a) Pekerjaan Atap

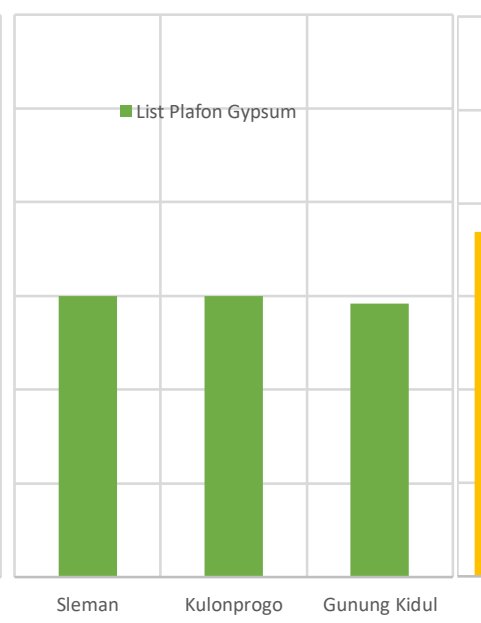

(b) Pekerjaan Langit-Langit

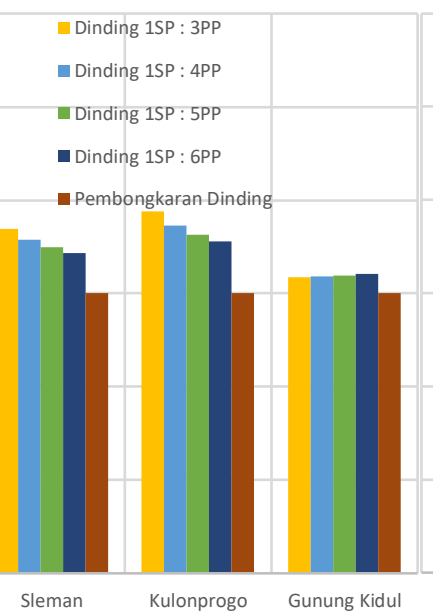

(c) Pekerjaan Dinding

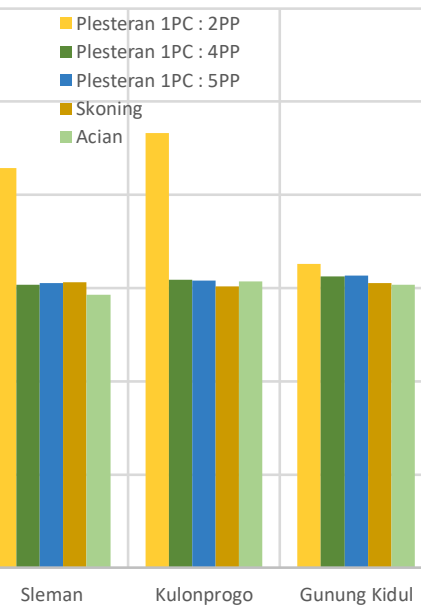

(d) Pekerjaan Plesteran
- Cat Tembok Lama - Cat Tembok Baru - Cat Kayu 112 - Cat Kayu 113 - Cat Besi - Pengerokan Cat

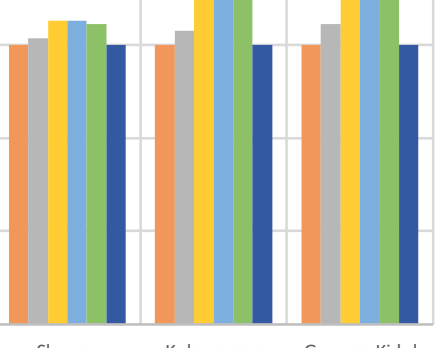

Sleman

(e) Pekerjaan Cat

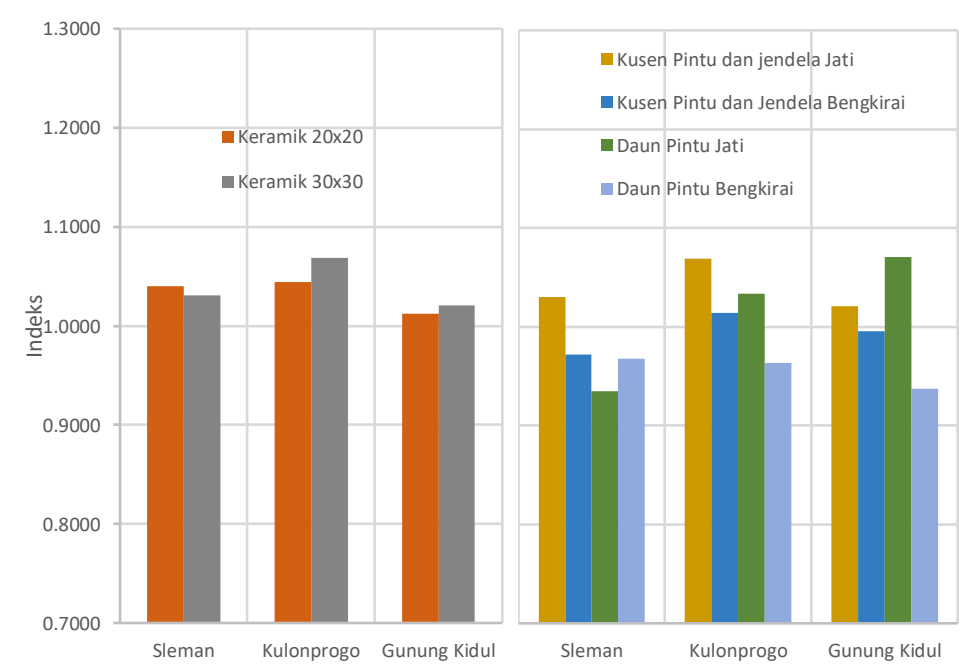

(f) Pekerjaan Penutup Lantai (g) Pekerjaan Pintu dan Jendela

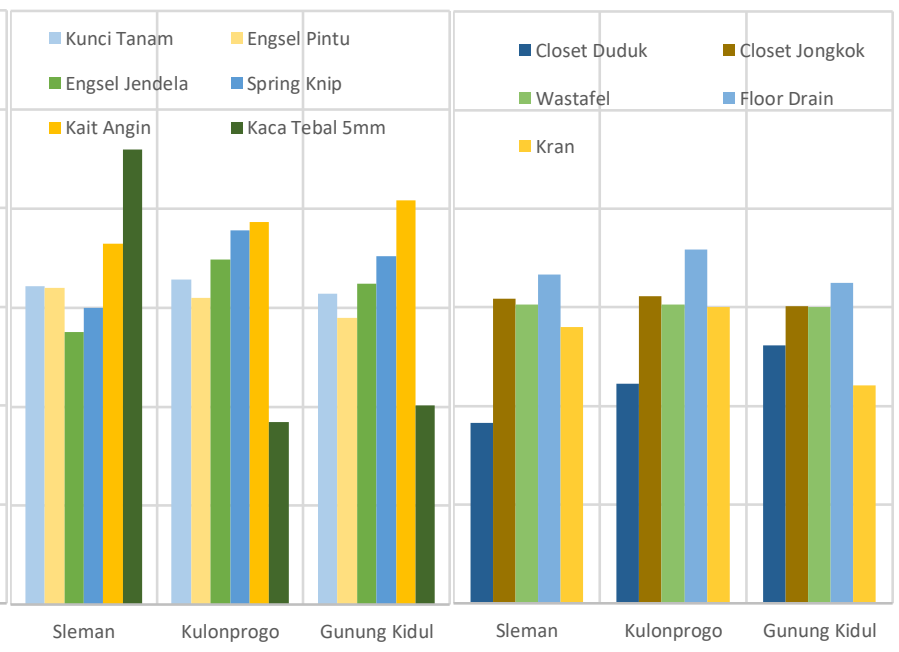

(h) Pekerjaan Kunci dan Kaca

Gambar 3. Indeks Lokasi Pekerjaan 
Pada Gambar 2 Pekerjaan Pemasangan 1 Buah Wastafel diperoleh persamaan

$Y=280914,3072 X-564767389,0295$

dengan nilai $\left(R^{2}\right)$ sebesar 0,4355 . Hal ini menunjukan bahwa pada pekerjaan Pemasangan 1 Buah Wastafel 43,55\% variasi variabel hargasatuan pekerjaan $(Y)$ dipengaruhi oleh variabel tahun (X) sedangkan sisanya $(100 \%-43,55 \%=$ $56,45 \%$ ) dipengaruhi oleh sebab-sebab lain yang tidak diteliti. Pada Gambar 2 Pekerjaan Pemasangan 1 Buah Closet Jongkok Porselen diperoleh persamaan

$Y=20251,4192 X-40386418,2441$

dengan nilai $\left(R^{2}\right)$ sebesar 0,025 . Nilai $\mathrm{R}^{2}$ yang didapatkan sangat rendah (kurang dari 0,1 ), hal ini dikarenakan basis data yang didapatkan pada pekerjaan tersebut memiliki keragaman data. Penyebab lainnya nilai $R^{2}$ yang sangat rendah (kurang dari 0,1 ) yang mana akan menyebabkan ketidaktepatan dalam mengestimasi harga satuan komponen pekerjaan bangunan gedung.

Model yang dianggap layak digunakan dalam mengestimasi harga satuan komponen pekerjaan bangunan gedung yaitu model yang memiliki nilai $\mathrm{R}^{2}$ lebih besar dari 0,7 atau mendekati 1. Semakin besar nilai $R^{2}$ (mendekati 1 ) menunjukkan bahwa sebaran data tidak terlalu beragam sehingga dapat mengestimasi HSP dengan tepat.
Berdasarkan hasil analisis diperoleh harga satuan komponen pekerjaan yang secara signifikan dipengaruhi oleh waktu dilihat dari nilai $R^{2}$ yaitu terdapat pada pekerjaan Pemasangan $1 \mathrm{~m}^{1}$ skoning $1 \mathrm{PC}: 2 \mathrm{PP}$ dengan nilai $R^{2}=0,9043$ (nilai $R^{2}$ mendekati 1). Secara keseluruhan model harga satuan komponenpekerjaan dapat dilihat di dalamTabel 9.

Pada Gambar 3 menunjukkan bahwa indeks lokasi pekerjaan kota Yogyakarta sebagai indeks dasar (indeks 1,000) pada HSP Pemasangan 1 Buah Closet Duduk/Monoblock di kabupaten Sleman, Kulonprogo dan Gunung Kidul sebesar 0,8833, 0,9222 dan 0,9611 lebih kecil dari 1,000 artinya HSP Pemasangan 1 Buah Closet Duduk/Monoblock di kabupaten Sleman, Kulonprogo dan Gunung Kidul lebih rendah dari pada kota Yogyakarta. Indeks lokasi pekerjaan HSP Pemasangan 1 Buah Closet Jongkok Porselen di kabupaten Sleman, Kulonprogo dan Gunung Kidul sebesar 1,0086, 1,0111 dan 1,0015 lebih besar dari 1,000 artinya HSP Pemasangan 11 Buah Closet Jongkok Porselen kabupaten Sleman, Kulonprogo dan Gunung Kidul lebih tinggi dari pada kota Yogyakarta.

Harga satuan pekerjaan di kota Yogyakarta yang lebih mahal dibandingkan kabupaten Sleman, Kulonprogo, Gunung Kidul disebabkan oleh komponen harga satuandi kota Yogyakarta harganya sangat tinggi, penambahan biaya transport dan biaya lainya mengakibatkan tingginya harga bahan di kota Yogyakarta.

Tabel 9. Model Harga Satuan Pekerjaan

\begin{tabular}{|c|c|c|c|c|}
\hline \multirow{2}{*}{ No } & \multirow{2}{*}{ Model Hasil Analisis } & \multirow{2}{*}{$\mathbf{R}^{2}$} & \multirow{2}{*}{$\begin{array}{c}\text { Ket. } \\
\text { Model }\end{array}$} & $\begin{array}{l}\text { Indeks Lokasi } \\
\text { Pekerjaan }\end{array}$ \\
\hline & & & & $\begin{array}{lll}\text { SLM } & \text { KP } & \text { GK }\end{array}$ \\
\hline & $Y=4008,7040 X-8000469,8642$ & 0,1679 & $\begin{array}{l}\text { Tidak } \\
\text { Layak }\end{array}$ & $0,98170,99990,9823$ \\
\hline & $\begin{array}{l}\text { Pemasangan } 1 \mathrm{~m}^{1} \text { Nok Genteng } \mathrm{Y}=3128,9497 \mathrm{X}-6219163,9860 \\
\text { Beton }\end{array}$ & 0,1791 & $\begin{array}{l}\text { Tidak } \\
\text { Layak }\end{array}$ & $1,06721,09311,0036$ \\
\hline
\end{tabular}




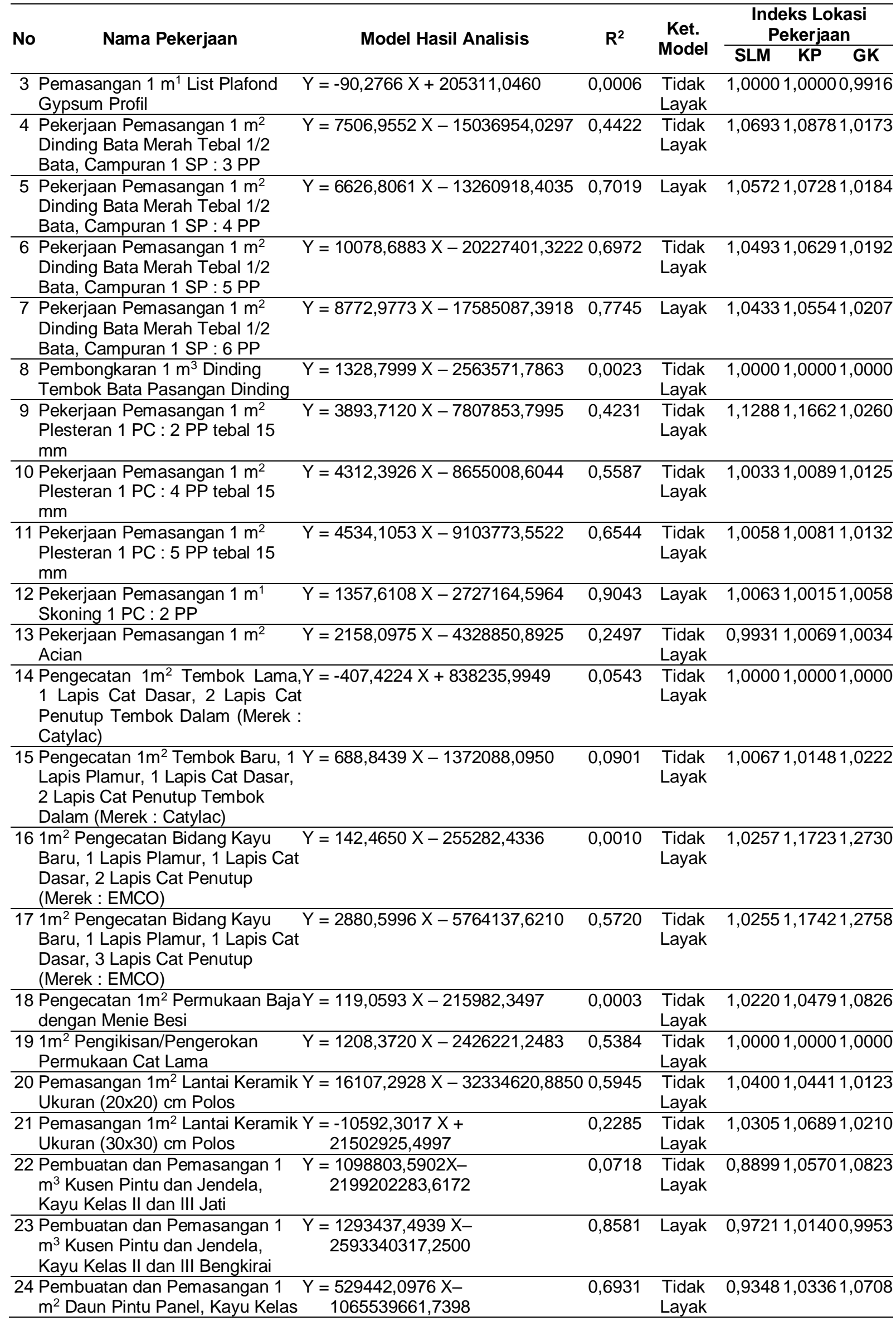


Model Analisis Harga ... (Vanita/ hal 118-132)

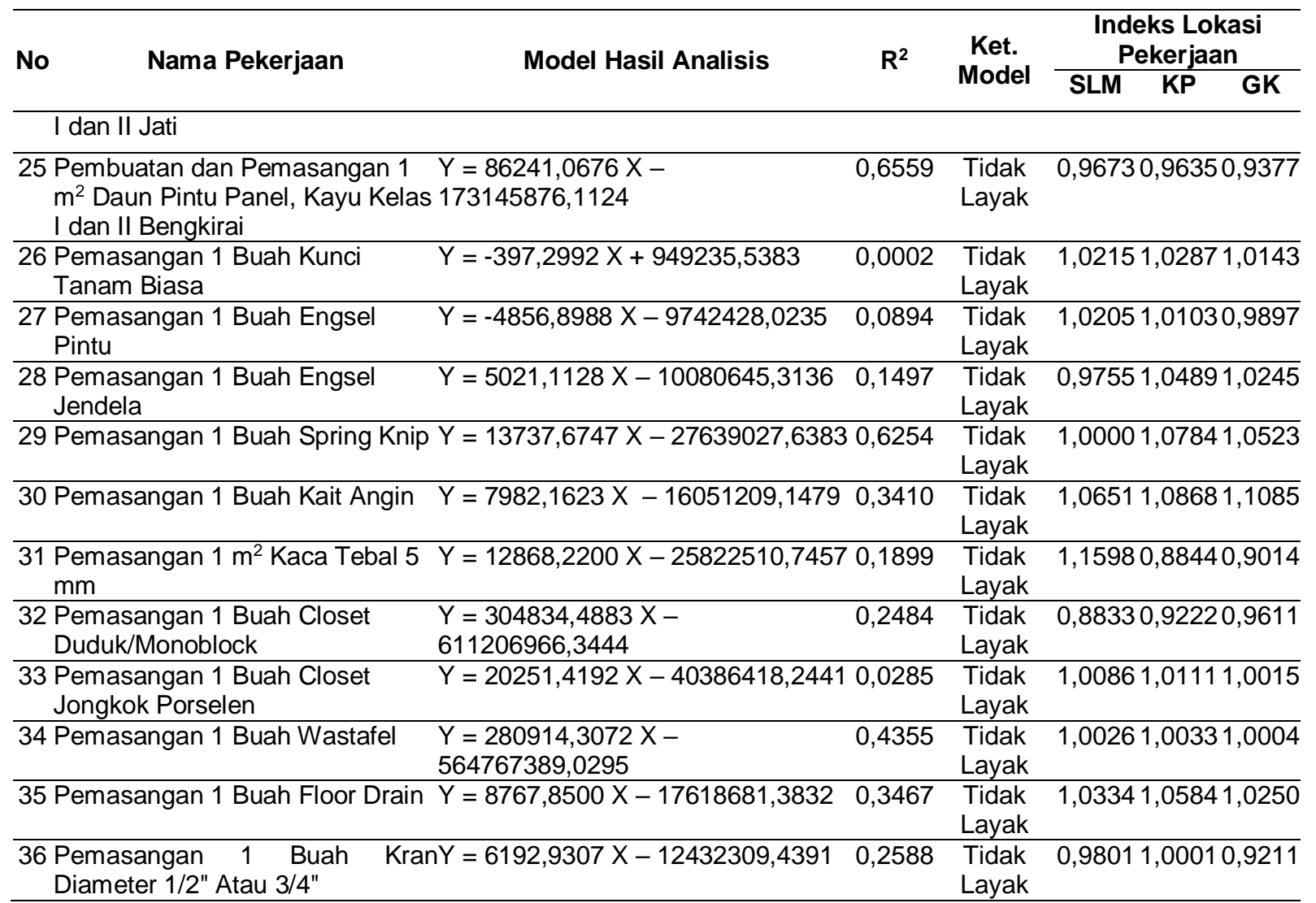

\section{Keterangan :}

$\mathrm{Y}$ : harga satuan pekerjaan di kota Yogyakarta

$\mathrm{X}$ : tahun

\section{SIMPULAN}

Berdasarkan hasil penelitian menunjukkan bahwa tidak semua model layak digunakan dalam mengestimasi harga satuan pekerjaan dikarenakan memiliki nilai $R^{2}<$ 0,7 . Dari 36 pekerjaan terdapat 32 pekerjaan memiliki nilai $R^{2}<0,7$ dan 4 pekerjaan memiliki nilai $R^{2}>0,7$ yaitu terdapat pada Pekerjaan Pemasangan 1 $\mathrm{m}^{2}$ Dinding Bata Merah Tebal 1/2 Bata Campuran 1 SP : 4 PP, Pekerjaan Pemasangan $1 \mathrm{~m}^{2}$ Dinding Bata Merah Tebal 1/2 Bata Campuran $1 \mathrm{SP}: 6 \mathrm{PP}$, Pekerjaan Pemasangan $1 \mathrm{~m}^{1}$ Skoning 1 PC : 2 PP dan Pembuatan dan Pemasangan $1 \mathrm{~m}^{3}$ Kusen Pintu dan Jendela, Kayu Kelas II dan III Bengkirai.

\section{DAFTAR RUJUKAN}

Ahmad Muali, 2015, Estimasi Biaya Konstruksi Bangunan Gedung dengan Metode Cost Significant Model, Skripsi, Universitas Sebelas Maret, Surakarta

Departemen Pekerjaan Umum, Direktorat Jenderal Cipta Karya, 2006, Pedoman Teknis Rumah dan Bangunan Gedung Tahan Gempa, Jakarta.

Departemen Pekerjaan Umum, Direktorat Jenderal Cipta Karya, 2008, Pedoman Pemeliharaan dan Perawatan Bangunan Gedung, Jakarta.

Fikri, R M., Sekarsari, J., 2015,Analisis Estimasi Biaya Proyek Peningkatan 
Jalan beton di Kabupaten Tangerang Dengan Metode Cost Significant Model, Seminar Nasional Teknik Sipil V Tahun 2015 - UMS, Solo.

H. Bachtiar Ibrahim , 2008, Rencana dan Estimate Real of Cost, Bumi Aksara, Jakarta.

Hence S.D. Roring, 2014, Model Estimasi Biaya Tahap konseptual Konstruksi Bangunan Gedung Dengan Metode Parametrik (Studi Kasus pada Bangunan Gedung Publik di Wilayah Kota Manado dan Kabupaten/Kota sekitarnya), Jurnal IImiah Media Engineering Vol.4 No.2 September 2014 hal 102-10, ISSN : 2087-9334.

Jennyvera, 2012,Estimasi Biaya Konseptual Pada Konstruksi Gedung Perkantoran Dengan Metode Fuzzy Logic, Universitas Indonesia, Jakarta.

Nasril, Jumas, D Y., 2014, Improving Conceptual Cost Estimating Performance Pada Perhitungan Harga Satuan Tertinggi Bangunan Gedung di Sumatera Barat, Jurnal Rekayasa Sipil Vol 10 No 1.

Touran A., Liu J.,2015Suatu metode untuk estimasi kontingensi berdasarkan kompleksitas proyek, Creative Construction Conference, Boston.

Iman Soeharto, 1995, Manajemen Proyek Dari Konseptual Sampai Operasional, Unit Penerbit dan Percetakan AMP YKPN, Yogyakarta.

Kissi, E.,Kumi, T.A., Badu E., Boateng, E.B., 2017, Factors Affecting Tender Price in the Ghanaian Construction Industry,Journal of Financial Management of Property and Construction
Pradnyadari, N L M A M., Yansen, W., Wiranata, A A., 2016, Estimasi Biaya Konstruksi Gedung Berdasarkan Indeks Harga Bahan dan Upah Tenaga Kerja(Kabupaten Badung dan Kabupaten Tabanan), Jurnal IImiah Teknik Sipil Vol 20 No 2.

Prihadi, W. R., \& Pratama, G. N. I. P. Konfigurasi Batang Pada Perancangan Rangka Atap Bambu. INERSIA, 12(2), 173-183.

Roring, H S D., Sompie, B F., Mandagi, R J M., 2014, Model Estimasi Biaya Tahap Konseptual Konstruksi Bangunan Gedung Dengan Metode Parametrik(Studi Kasus Pada Bangunan Gedung Publik di Wilayah Kota Manado dan Kabupaten/Kota sekitarnya), Jurnal Ilmiah Media engineering Vol 4 No 2.

Sariani, N L A, 2011, Estimasi Biaya Konstruksi Gedungdengan Metode Cost Significant Model(Studi Kasus Proyek Konstruksi Gedung Pemerintah di Kabupaten Jembrana), Universitas Udayana, Denpasar.

Sae-Hyun Ji, 2010, Data PreprocessingBased Parametric Cost Model For Building Projects: Case Studi of Korean Construction Project, Journal of Construction Engineering and Management Vol.136 No.8 August 1 2010 hal 844-853, ASCE. 